\title{
A travessia da favela nas SERras do CAMbaiO
}

Rômulo Monte Alto

UFMG

\begin{abstract}
RESU M O
Este artigo busca refletir sobre o episódio da travessia do Cambaio, no livro Os sertões (1902) de Euclides da Cunha. Examina a construção do espaço do conflito a partir do pressuposto de que a fundação da nação latino-americana, aqui tomada como uma hipérbole da nação brasileira, incorporou princípios de corte excludente que dividiram o país em regiões de atraso e de progresso, o que resultou numa estranha profecia que se cumpriu cem anos depois.
\end{abstract}

\author{
PALAVRAS-CHAVE \\ Sertão. Nação. Canudos.
}

Muito baixo no horizonte, o sol descia vagarosamente, tangenciando com o limbo rutilante o extremo das chapadas remotas e o seu último clarão, a cavaleiro das sombras, que já se adunavam nas baixadas, caía sobre o dorso da montanha... Aclarou-o por momentos. Iluminou, fugaz, o préstito que seguia à cadência das rezas. Deslizou, insensivelmente, subindo, à medida que lentamente ascendiam as sombras, até ao alto, onde os seus últimos raios cintilaram nos píncaros altaneiros. Estes fulguravam por instantes, como enormes círios, prestes acesos, prestes apagados, bruxuleando na meia luz do crepúsculo.

Brilharam as primeiras estrelas. Rutilando na altura, a cruz resplandecente de Orion alevantava-se no sertões...

Euclides da Cunha. Os sertões

\section{Agonia e êxtase no Cambaio}

\begin{abstract}
A descrição do pôr do sol na serra do Cambaio, após um dia de duras refregas entre conselheiristas e soldados, impressiona pela riqueza pictórica e a exuberância barroca dos detalhes, especialmente pelo contraste que estabelece com a anterior descrição de um cortejo fúnebre que seguia para o arraial de Antonio Conselheiro. A grandiloqüência do fragmento testemunha o olhar melancólico de seu autor sobre a onipotência da natureza, que se opõe incólume ao desastre humano que aquelas serras acabavam de assistir e apresenta um dos muitos momentos do livro em que a literatura se descola do contexto imediato para mergulhar num discurso autotélico. Produto da imaginação incansável de Euclides da Cunha, o escritor misto de engenheiro e repórter que acompanhou a última expedição do Exército brasileiro a Canudos, em 1897, o relato
\end{abstract}


da travessia foi reconstruído com base em conversas e depoimentos que seu autor recolheu entre personagens que viveram aquele drama. Mais que o cenário de um capítulo sangrento na história das campanhas que se realizaram contra Canudos, a travessia do Cambaio prenuncia o anticlímax de uma guerra que não teve vencedores ou vencidos, confirmando a sugestão de que suas encostas seriam testemunhas não apenas de uma época na história do país que chegava a seu fim, mas de uma maneira específica de escrever sobre essa época, própria da narrativa euclidiana.

Monte Santo, o povoado que recebe a "primeira expedição regular" contra Canudos, só existe dentro do relato fundacional de Os sertões como um local significado pelo discurso institucional da história, manejado por Euclides como referente de autoridade: "Não surgia pela primeira vez na história". ${ }^{1}$ A vila faz sua aparição para a nacionalidade na referência aos bandeirantes que por lá passaram no século XVII e aos soldados que agora chegam para a batalha, os antigos e novos "devassadores do sertão", homens com uma "função histórica", à procura de lendas que falavam de "minas de prata" ontem, e de "pátria, glória e liberdade" hoje. Seu passado como centro de peregrinação se vincula a uma préhistória dos costumes, ligado à "religiosidade ingênua dos matutos", que talharam com seus passos "a mais bela de suas ruas - a via-sacra dos sertões", como a ilusão de uma escada que subisse aos céus. Christian Hausser afirma que "a exclusão da história como instância maior significa ao mesmo tempo a exclusão como parte igual da nação brasileira”. Fora da história, à margem da memória oficial, restava aos indivíduos e comunidades desamparados daquela região da Bahia a escadaria como alegoria da proteção estatal, ou, em outras palavras, o anteparo que encontravam para fazer frente às suas demandas consistia numa subida íngreme na qual se reconheciam como iguais participantes de uma mesma comunidade sacrificial.

Por ali se acantonou a tropa, num delírio de feira acompanhado de banquete, risos, clarins e discursos inflamados, justificado pelas "portentosas armas da civilização", que faziam estremecer os "titãs enrijecidos [...] dentro de suas armaduras de couro". Mostrava seus músculos: dois canhões Krupp $7^{1 / 2}$, duas metralhadoras Nordenfeldt e muitas carabinas Mannlincher. Seu contraponto eram "as preces abafadas dos fiéis genuflexos...", imagem paródica das confabulações em voz baixa, das conversas a boca miúda, dos cochichos subversivos, gestos pequenos pelos quais os espiões disfarçados relacionam o inimigo e seu poder de guerra. Os primeiros dormem com a certeza da vitória porque sonham com o cumprimento de uma missão: "Era preciso um grande exemplo e uma grande lição. Os rudes impertinentes [...] requeriam corretivo enérgico. Era preciso que saíssem afinal da barbaria em que escandalizavam o nosso tempo, e entrassem repentinamente pela civilização

\footnotetext{
${ }^{1}$ CUNHA. Os sertões, p. 173. Afirmar que Euclides maneja a história em seu texto pode parecer um equívoco e até uma ousadia, mas o certo é que a visão oficial que permaneceu no imaginário sobre o conflito de Canudos veio de seu relato, o que levou Walnice Nogueira Galvão a afirmar que foi a literatura que manteve Canudos na memória popular e na grade histórica nacional. Ou como afirma Christian K. Hausser: "O que fez com que a campanha sangrenta entrasse na memória nacional foi a sua representação literária na obra de Euclides da Cunha." (HAUSSER. A Guerra de Canudos na memória nacional: os manuais de história, p. 157-172.)
}

${ }^{2}$ CUNHA. Os sertões, p. 176. As citações futuras de Os sertões virão seguidas do número da página entre parênteses. 
a dentro, a pranchadas". ${ }^{2}$ Os segundos confiam na vitória por saber que, paradoxalmente, fazem parte de uma nação, uma "família espiritual" (de fiéis), assim como a definia Renan, que não se vincula apenas pelo território que ocupam, mas pela realização diária de um plebiscito, no qual expressam o desejo de continuar vivendo juntos e pelo qual fazem qualquer sacrifício. Não por acaso serão chamados de "mártires da fé", homens e mulheres que oferecem suas vidas para defender Canudos, avançando sobre o fogo aberto dos soldados sem ter nas mãos mais que varapaus, foices, forquilhas ou facões, como no episódio de Uauá, ou na emboscada de Tabuleirinhos. História e religião aparecem no texto não apenas como suportes discursivos a justificar as práticas das personagens, mas como formas autônomas de conhecimento motivadas para uma guerra santa, como sugere Roberto Ventura: "Canudos foi o ponto central de definição da forma republicana no Brasil, pela conversão da campanha militar em cruzada revolucionária.”

A natureza na narrativa euclidiana não é apenas exuberância expectadora, mas é convocada para participar ativamente nas lutas que se dão em seus domínios. As massas do Cambaio, descritas com um viés de cunho romanesco, resumem um cenário tenebroso para onde se encaminham os soldados ao saírem de Monte Santo:

as massas [...] recortadas de gargantas longas e circulantes como fossos, [como] necrópoles vastas $[\ldots]$ grandes cidades mortas ante as quais o matuto passa, medroso; $[\ldots]$ aqueles redutos bárbaros [...] barbacãs de velhíssimos castelos, onde houvesse embatido, outrora, assaltos sobre assaltos que os desmantelaram, reduzindo-os a montões de silhares em desordem, mal aglomerados em enormes hemiciclos, sucedendo-se em renques de plintos, e torres, e pilastras truncadas, avultando mais ao longe no aspecto pinturesco de grandes colunatas derruídas. ${ }^{4}$

São ruínas, descritas com as referências que reverenciam outras ruínas, as dos textos medievais, revelando a melancolia do narrador pelo mundo que está prestes a acabar. Em seu desejo de fixar as imagens que o futuro se encarregará de traduzir, escava a memória para encontrar num tempo passado os termos com os quais deverá significálas. ${ }^{5} \mathrm{Na}$ reedição dessa epopéia arcaica, a natureza é um "personagem dramático, que projeta imagens e sombras sobre a narrativa"; ${ }^{6}$ é contra ela que investem os soldados ("a terra protetora dava aos vencidos seu último reduto"), é com seus fragmentos que os sertanejos vão contar para poder açoitar a tropa em sua marcha de volta a Monte Santo. A partir dessa perspectiva se poderia sugerir a leitura do texto da epígrafe como uma saudação da natureza aos mortos que seguem em procissão para o arraial.

Os fanáticos de Antonio Conselheiro, à espreita no alto da serra, são também extensão dessas ruínas fantasmagóricas: "rentes com o chão, rebatidos nas dobras dos terrenos, entaliscados nas crastas..." São combatentes ou fantasmas, não se sabe ao certo, porque parecem não morrer: "os soldados viam tombar, mas ressurgir imediatamente, indistinto pelo fumo, o mesmo busto, apontando-lhes a espingarda. Alvejavam-no de novo.

\footnotetext{
${ }^{3}$ VENTURA. Retrato interrompido da vida de Euclides da Cunha, p. 171.

${ }^{4}$ CUNHA. Os sertões, p. 183, 184.

${ }^{5}$ Walter Benjamin sugere a imagem da melancolia associada ao ato de "cavar". LAGES. Entremeio: a melancolia em Walter Benjamin, p. 99-159.
}

${ }^{6}$ VENTURA. Retrato interrompido da vida de Euclides da Cunha, p. 201. 
Viam-no outra vez cair, de bruços, baleado. Mas viam outra vez erguer-se, invulnerável, assombroso, terrível, abatendo-se e aprumando-se, o atirador fantástico"(p. 185). Reencarnam um dos mitos da literatura da Reconquista Espanhola, Rodrigo Díaz de Vivar, conhecido como El Mío Cid Campeador, o cavaleiro que mesmo morto apareceu ressurecto sobre seu imponente cavalo, infringindo pavor sobre as hostes inimigas e confirmando a imortalidade dos que guerreiam pelas causas santas. Seu ataque quixotesco se faz com tiros de clavinotes, espingardas de pederneiras, trabucos de canos largos, juntamente com "brados escandalosos", "apóstrofes insolentes", seguidas de carreiras nas quais inventam "figurações selvagens", imagens distorcidas de homens que desaparecem, cavaleiros inexistentes que, como Agilulfo de Italo Calvino, possuíam como única arma a "força de vontade [...] e fé [na] santa causa!" Como expressões arcaicas de um tempo em que as guerras supunham gestos heróicos e espetáculos pirotécnicos, se opõem ao matraqueio rotineiro das armas modernas e das clássicas formações de guerra prussiana. No alto da serra, surgem como habitantes das necrópoles em ruínas, "almas do outro mundo" ensaiando sua "arruaça sinistra". Lá embaixo, impávidas, as máquinas da civilização atravessam o vale da morte, produzindo mais ruína em sua passagem, vide o saldo dos combates na travessia: "quatro mortos e vinte e tantos feridos", da parte dos soldados, e cento e quinze cadáveres entre os sertanejos, "contados rigorosamente".

À saída da serra, em marcha acelerada, o destacamento pernoita em Tabuleirinhos, de onde pretende arremeter sobre o arraial, na manhã seguinte. Porém, novamente os guerreiros fantasmas de Antonio Conselheiro avançam sobre as tropas, num arremedo insano das táticas de combate dos cavaleiros medievais, como o sítio ao redor dos inimigos e as correrias para confundi-los: "Apenas repelidos, num retroceder repentino que não era uma fuga, mas uma negaça perigosa, fervilhavam no matagal rarefeito, em roda: vultos célebres, fugazes, indistintos, aparecendo e desaparecendo nos claros das galhadas". Isso provoca pavor e desgaste em lugar de uma derrota real e faz com que a tropa extenuada decida recuar para Monte Santo, em razão da pouca munição e da falta de comida e água. Novamente não há comparação quanto ao resultado do confronto: quatro baixas e uns vinte feridos entre os soldados, e mais de trezentos mortos entre os sertanejos, segundo apurou um dos médicos da expedição. Foi um massacre.

A travessia de volta do Cambaio oferece imagens de mártires em fuga, descritas pelo narrador com grande tragicidade épica, possivelmente com o fim de enfatizar o sofrimento dos soldados (uma "multidão de espectros" fustigados por "uma turba vingadora de demônios") e engrandecer seu feito perante a história. Entretanto, sinaliza também para uma distensão de sentido entre os conceitos barbárie e civilização, deixando à mostra a existência de um espaço suplementar de significação (o "terceiro espaço" de Bhabha?), a partir do qual o texto vai desenhando linhas de fuga para uma narrativa que já não consegue se segurar sobre a "linha reta" que, como um meta-relato previamente definido pela autoria, desmorona a cada novo enunciado, como nessa referência ao modo como a tropa se banqueteia sobre um rebanho de cabras perdidas: "andrajosos, imundos, repugnantes - agrupavam-se, tintos pelos brasões dos braseiros, os heróis infelizes, como um bando de canibais famulentos em repasto bárbaro..." (p. 194). Esta

${ }^{7}$ CALVINO. O cavaleiro inexistente, p. 10. 
será talvez a marca indelével que o autor imprime sobre sua obra e a terá celebrizado como a "bíblia da nacionalidade", segundo Joaquim Nabuco: a criação do sertão como uma zona de distensão dos sentidos, uma região em que os conceitos retornam a seu estado primitivo de metáforas, recuperando sua labilidade ao se negar a insistir no processo de "igualação do não-igual". ${ }^{8}$ Isso dá lugar à negociação como estratégia de resistência entre elementos irredutivelmente antagônicos, suspendendo as sínteses conciliadoras, como forma de obstruir as polaridades que o discurso possa sugerir. ${ }^{9} \mathrm{Um}$ lugar que Guimarães Rosa reinventou meio século depois com uma frase singular: "Lugar sertão se divulga: é onde os pastos carecem de fecho". É nessa terra imaginária e imaginada que o autor realiza sua catarse pessoal, projetando seu deserto interior, lugar em que suas conclusões parecem oscilar a cada passo, mas não sua forma de relatá-las. É o que sugere um olhar mais atento sobre o trabalho da sua autoria.

\section{O Intelectual e SEU deserto}

Acredito porém que isto durará pouco, não dou para a vida sedentária, tenho alguma coisa de árabe - já vivo a idealizar uma vida mais movimentada, numa comissão qualquer arriscada, aí por estes sertões desertos e vastos de nossa terra, distraindo-me na companhia simples e feliz dos bugres. Se o meu velho for, agora como intenta, à Europa, irei com ele; eu sinto necessidade de abandonar por algum tempo o meio civilizado da nossa terra: assim ou aspiro os sertões desertos ou as grandes capitais estrangeiras - hei de seguir para um destes destinos daqui a alguns meses. ${ }^{10}$

Euclides é um homem melancólico, atormentado pelo tédio irremediável que o acossa em qualquer lugar que esteja. Sonha com os interiores, mas em movimento: "desejo o sertão, a picada malgradada, e a vida afanosa e triste de pioneiro". Sente-se bem quando viaja, pois, segundo Roberto Ventura, "viajar era de certa forma escrever". Sua correspondência revela um homem urbano em conflito com as novidades que transformam as grandes cidades nas quais vive, sonhando com o idílio de uma vida pacata num lugarejo do interior. Elabora, em carta a seu amigo João Luís, um dístico irreparável: "estou condenado à poeira das aldeias grandes desta terra sem cidades."11 Mais que o sentimento romântico de desajuste de final de século, Ventura vê aí um retorno às emoções perdidas da infância, quando cresceu em ambientes bucólicos e teve que se mudar para cidades como Salvador e Rio de Janeiro, num trajeto de errância que se agravou com a morte de sua mãe. No entanto, o deserto parece estar relacionado à escrita de sua própria história, como oposição a algo que aspira à plenitude. Em Manaus, quando esperava a partida para realizar os levantamentos fronteiriços da Expedição ao Purus, escreve a seu amigo Coelho Neto, comentando sua ansiedade com a demora da partida: "Não te direi os dias que aqui passo, a aguardar o meu deserto, o meu deserto

\footnotetext{
${ }^{8}$ NIETSZCHE. Sobre verdade e mentira no sentido extramoral, p. 56.

${ }^{9}$ Toda essa reflexão anterior se apropria dos termos com que Homi Bhabha discute o lugar da teoria e do discurso crítico perante o engajamento político. BHABHA. O local da cultura, p. 43-69.

${ }^{10}$ GALVÃO. Correspondência de Euclides da Cunha, p. 38.

${ }^{11}$ GALVÃO. Correspondência de Euclides da Cunha, p. 102.
} 
bravio e salvador onde pretendo entrar com os arremessos britânicos de Livingstone e a desesperança italiana de um Lara, em busca de um capítulo novo no romance malarranjado desta minha existência." 12 O deserto tem a aparência de seu duplo, o outro com quem tem um encontro marcado, um território no qual inscrever-se, como afirma Ventura: "as visões do deserto fornecem pistas a serem trilhadas pelo narrador-viajante, batedor do processo histórico e civilizatório."13

Para este crítico, no entanto, o deserto e os sertões, mais que espaços vazios ou selvagens, estão relacionados aos espaços sem escrita, sem representação, espaços que por isso se encontram fora da história:

Os sertões, quer nordestinos, quer amazônicos, são desérticos, espaços vazios, fora da escrita e da civilização. Ao decifrar a caatinga e a floresta e resgatar o sertanejo do esquecimento, o narrador-viajante os insere na história. No relato de viagem ou no ensaio histórico, na notação literária e científica, a natureza se converte em livro, imagem inscrita no seu cerne ou essência. (p. 247)

Descrever o sertão e o deserto era inseri-los num discurso de outra amplitude, era colocálos para dentro do discurso oficial da nacionalidade. Um gesto que na modernidade exige um sujeito centrado, uma perspectiva totalizante e um discurso científico - seria aquela "linha reta" que traçou para sua vida, a expressão de Euclides para esse sujeito? Mas se, como afirma Benjamin, "a verdade é inseparável de sua apresentação", ${ }^{14}$ o texto também deve conter em sua sintaxe a escorregadia expressão do vazio que pretende descrever. Se o sujeito moderno padece de sua problemática projeção sobre o enunciado, a autoreflexividade produzida pela linguagem se torna um problema: a mesma narrativa que apreende e descreve o objeto leva impresso em seu dorso o sujeito do discurso. Escrever o deserto para Euclides se torna, assim, a projeção de si mesmo na folha em branco que a letra deve sulcar, o percurso a ser vencido paulatinamente pela força das palavras, como meio de encontrar seu assento nesse mesmo relato nacional, que chamou de civilização. ${ }^{15}$

Seu método de trabalho é o de um copista, como confessa em carta a Joaquim Nabuco: "Releve-me esta verdade, o Dante, para zurzir os desmandos de Florença, idealizou o inferno; eu, não, para bater de frente alguns vícios de nosso singular momento histórico, copiei, copiei apenas, incorruptivelmente, um dos seus aspectos... e não tive um Virgílio a amparar-me o furor dos condenados!"16 Para além da alegoria menardiana

\footnotetext{
${ }^{12}$ GALVÃO. Correspondência de Euclides da Cunha, p. 266.

${ }^{13}$ VENTURA. Retrato interrompido da vida de Euclides da Cunha, p. 248. Ana Luiza Andrade, em artigo em que analisa Euclides a partir de Gilberto Freyre, afirma que o sociólogo relaciona a descrição da paisagem desértica à personalidade do próprio autor, sugerindo a existência de uma "colagem híbrida de homem-paisagem". (ANDRADE. Nordeste desertificado e docilizado, p. 23-37)

${ }^{14}$ LAGES. Entremeio: a melancolia em Walter Benjamin, p. 125.

${ }^{15}$ Outra hipótese que sustenta este argumento: um ano antes da viagem a Canudos, Euclides estudava mineralogia e geologia para um concurso na Escola Politécnica, que se abriria em São Paulo, mas que não chegou a se realizar; poderia Os sertões ser tomado como uma aula pública sobre os temas que tanto ansiava ensinar e que nunca lhe permitiram, uma vez que publicá-los no jornal era expô-los a um público maior que o da escola?

${ }^{16}$ GALVÃO. Correspondência de Euclides da Cunha, p. 186. No livro, enquanto descreve o mestiço, Euclides reafirma sua prática: "Sejamos simples copistas." (p. 79, 80)
} 
da escrita como apropriação, o que faz Euclides, além de devorar autores, livros, diários de oficiais e amigos que o ajudaram na descrição de áreas e fatos desconhecidos, é parafrasear e copiar trechos de obras científicas e literárias, inserindo-os em seu texto, o que não passará desapercebido à época. Num ensaio publicado logo após o lançamento do livro, José de Campos Novaes, botânico, presidente do Centro de Ciências, Letras e Artes de Campinas, tece uma série de críticas ao texto euclidiano, afirmando primar aquela obra pelas "generalizações prematuras", por suas páginas com "ares rebarbativos" e "frases evidentemente inexatas por excessivamente imaginosas". Investe sobre o autor, ao se perguntar por sua atitude de fazer "tábula rasa atrás de si", quando ele se referia a Martius e outros cientistas que não penetraram até determinadas regiões do sertão, comentando sua leitura mal feita, ou até mesmo não feita, da obra daquele naturalista, e sugere que houve cópia de fragmentos da obra do botânico viajante. Sobre a construção da personagem do beato, afirma que se trata de um décalque, do Montanus de Renan, insinuando o "modo por demais imitativo com o qual [Euclides] reconstituiu a personalidade religiosa do Conselheiro."17

Além de copista assumido ou parafraseador dissimulado, Euclides escreve com exageração, "segundo o hábito dos narradores do sertão", o que se torna uma autoinscrição de sua escrita no texto que produz. Ao se definir como um "misto de celta, de tapuia e grego", evoca, segundo Ventura, uma herança situada entre a "educação brasileira e a cultura greco-francesa, que o levara à retórica clássica e à ciência naturalista", reivindicando sua distância epistemológica frente ao trabalho da narração. Exerce, com toda propriedade, o direito de se servir da biblioteca universal, ou ocidental, para a qual também contribui com seu texto repleto de referências clássicas. ${ }^{18}$ Porém, nas margens de seu texto, que falava de atos de heroísmo e bravura, fazia sua aparição um subtexto subversivo, "aqueles palimpsestos ultrajantes", deixados pelos soldados ao longo da rota para Canudos: "Sem a preocupação da forma, sem fantasias enganadoras, aqueles cronistas rudes deixavam por ali, indelével, o esboço real do maior escândalo da nossa história [...] sem uma frase varonil e digna." Sobre este texto rude, Euclides escreve o seu, tendo-o como fantasma da própria escrita, como uma sombra que penetra inconscientemente no imaginário nacional e descobre, sob seus textos oficiais, os traços de todos os outros textos calados, silenciados pela força desumana com que a cultura letrada escreve a história da nação.

Euclides possivelmente terá lido Sarmiento, pois quando da publicação de Os sertões pede que um exemplar seja enviado ao General Bartolomeu Mitre, em Buenos Aires, o que suporia algum conhecimento sobre a realidade do país vizinho. ${ }^{19}$ Ler o escritor argentino implica evocar similitudes e diferenças entre as obras, que se constroem

\footnotetext{
${ }^{17}$ NASCIMENTO. Juízos críticos, p. 112-122. A sugestão de paráfrase entre a obra de Euclides e o livro de Afonso Arinos, Os jagunços, publicado em 1898, é reconhecida por vários críticos; ver SALLES. Cicatrizes submersas d'os sertões, p. 49.

${ }^{18}$ Ver, a propósito, a belíssima descrição da biblioteca de Euclides feita por seu amigo, Coelho Neto, em NASCIMENTO. Juízos críticos, p. 108.

${ }^{19}$ Berthold Zilly confirma a leitura do Facundo por parte de Euclides, porém num ensaio chamado Martin Garcia, posterior ao Sertões. ZILLY. A barbárie: antítese ou elemento da civilização? Do Facundo de Sarmiento a Os sertões de Euclides da Cunha, p. 294.
} 
consoante normas parecidas; no entanto, ele se distancia de Sarmiento ao reivindicar a mediação daquilo sobre o que parece anunciar a extinção. ${ }^{20} \mathrm{O}$ escritor argentino utiliza a imagem da barbárie para prefigurar o fim de uma época, fixando na memória nacional tipos e costumes que serão extintos, mediante a marcha inexorável da civilização e do progresso que a tudo devora em seu caminho. Já seu correlato brasileiro parece renunciar, ao longo da narrativa, a suas convicções sobre a natureza dos personagens, bem como das razões do conflito, para se oferecer, anos depois, como seu representante perante a história, como comenta na iminência da publicação de seu livro: "Por uma das cláusulas, sairá à luz, em fins de abril do [ano] vindouro. Já vês que os pobres jagunços [...], afinal, que dessem a palavra ao seu [...] advogado diante da História. E este papel satisfaz inteiramente a minha vaidade". ${ }^{21}$

No entanto, ao rever posteriormente seus juízos sobre os jagunços, que passam progressivamente de "famigerados facínoras" a "nossos infelizes patrícios sertanejos", oferece a eles um lugar na genealogia nacional, passo que lhes garante a única possibilidade de fazer parte de um discurso histórico, uma vez que o desejo da nação se inscreve no código da família, conforme sugere Cornejo Polar. Euclides acede, assim, ao critério fundamental para requerer para sua obra o caráter fundador da nacionalidade, ao homogeneizar e incluir no relato da "unidade nacional" uma série de elementos heterogêneos dispersos pelo país, bem como para exercer seu papel de mediador, ou "advogado", daqueles sobre os quais narrou a derrota. ${ }^{22}$ Isso revela, por um lado, o elemento perverso que supõe toda e qualquer mediação regida pela letra, bem como o caráter violento dessa mediação, e por outro, a faceta ambígua das relações do intelectual latino-americano com o Estado e suas instituições.

As derradeiras páginas de Os sertões anunciam, de maneira temerosa, a impossibilidade de o narrador descrever as cenas finais do conflito: "Não há o que relatar o que houve a 3 e 4"; "Fechemos este livro"; "Forremo-nos à tarefa de descrever os seus últimos momentos. Nem poderíamos fazê-lo. Esta página, imaginamo-la sempre profundamente emocionante e trágica; mas cerramo-la vacilante e sem brilhos” (p. 406, 407). A literatura suspende o tempo da narrativa e se cala, na iminência da derrocada do sentido humanizador que a palavra carrega; percebe que o naufrágio do relato é também o do próprio narrador, que se salva ao interpor sobre o relato histórico o aspecto

\footnotetext{
${ }^{20}$ Extinção essa que se confirma em vários textos críticos posteriores, como o discurso de Sílvio Romero, em que saúda a entrada de Euclides para a Academia Brasileira de Letras: "Vós vos referistes aos esquecidos e desavisados sertanejos de entre o Itapicuru, da Bahia, e o Parnaíba, do Piaúi. Não vejo motivo para essa seleção da morte, essa escolha dos que vão desaparecer". ROMERO. Discurso pronunciado aos 18 de dezembro de 1906, por ocasião da recepção do Dr. Euclides da Cunha na Academia Brasileira de Letras, p. 156. Na verdade, mais que um mundo prestes a se acabar, o que está em extinção é a maneira de relatar este mundo, que nunca mais o será com o mesmo vocabulário exuberante, como fez Euclides da Cunha. ${ }^{21}$ GALVÃO. Correspondência de Euclides, p. 129.

${ }^{22}$ Roberto Ventura recorda que no nascimento da Academia Brasileira de Letras, em 1896, Machado de Assis deixava claro o objetivo maior da entidade: "O vosso objetivo é conservar, no meio da federação política a unidade literária." Assim, a literatura se apresentava no campo da política, legitimando a jovem República brasileira através da preservação de uma requerida unidade literária, que se organizava em torno de uma unidade lingüística e cultural. VENTURA. Retrato interrompido da vida de Euclides da Cunha, p. 146.
} 
ficcional da palavra, que emerge como alegoria de um tempo que se esvai. A obsessão do escritor com os detalhes estilísticos a serem corrigidos nas primeiras edições de Os sertões, desprezando a correção de dados que estariam em desacordo com a realidade, segundo Walnice Galvão, reitera sua preocupação com o sentido literário da obra, em detrimento do seu aspecto histórico, que já sabia equivocado. ${ }^{23}$ Por outro lado, reporta ao que Benjamin definia como uma busca impossível do melancólico: a correção da linguagem como desejo messiânico de resgatar o passado num tempo futuro. ${ }^{24} \mathrm{O}$ escritor do futuro, como se referia a si mesmo e a sua obra, ${ }^{25}$ não desconfia que as imagens que se recusa a descrever retornariam, na história da humanidade, como manifestações de uma civilização que carrega em seu ventre a pulsão violenta da barbárie, antevista naqueles rincões miseráveis do nordeste brasileiro, no final do século XIX:

Canudos tinha muito apropriadamente, em roda, uma cercadura de montanhas. Era um parêntese; era um hiato; era um vácuo. Não existia. Transposto aquele cordão de serras, ninguém mais pecava.

\section{$[\ldots]$}

A animalidade primitiva, lentamente, expungida pela civilização, ressurgiu, inteiriça. Desforrava-se afinal. Encontrou nas mãos ao invés do machado de diorito e do arpão de osso, a espada e a carabina. Mas a faca relembrava-lhe melhor o antigo punhal de sílex lascado. Vibrou-a. Nada tinha a perder. Nem mesmo o juízo remoto do futuro.

Mas que entre os deslumbramentos do futuro caia, implacável e revolta; sem altitude, porque a deprime o assunto; brutalmente violenta, porque é um grito de protesto; sombria, porque reflete uma nódoa - esta página sem brilhos... (p. 382)

\section{A LUTA DA SUCURI FLEXUOSA CONTRA O TOURO PUJANTE}

Qual era, afinal, a condenação que pairava sobre Canudos para que sobre ele recaísse a ira nacional? Segundo o próprio Euclides, "um apego estúpido às mais antigas tradições", um "apelar constante para o maravilhoso", era sua culpa gravíssima, o que, por uma equação duvidosa na qual entravam interesses políticos variados, colocava em risco a própria República recém-criada. ${ }^{26}$ Esse apego desmedido a tradições arcaicas é o que mantinha aquela comunidade separada da nação brasileira por um lapso de tempo secular:

\footnotetext{
${ }^{23}$ GALVÃO. O Império do Belo Monte. Isso nega a afirmação do próprio Euclides de que não se preocupava com o destino literário de seu livro, mas sim com o "mérito único da sinceridade" que aquele possuía, em carta a José Veríssimo, de 24 de janeiro de 1901.

${ }^{24}$ LAGES. Entremeio: a melancolia em Walter Benjamin, p. 149.

${ }^{25}$ GALVÃO. Correspondência de Euclides da Cunha, p. 144. Como disse Cornejo Polar, toda a literatura de fundação se dirige não apenas a seu público imediato, mas também às gerações futuras.

${ }^{26}$ Segundo Roberto Ventura, "a destruição de Canudos se deveu menos ao anti-republicanismo do Conselheiro do que a fatores políticos, como os conflitos entre facções partidárias na Bahia, a atuação da Igreja contra o catolicismo pouco ortodoxo dos beatos e as pressões dos proprietários de terras contra Canudos, cuja expansão trazia escassez de mão-de-obra e rompia o equilíbrio político da região" VENTURA. Retrato interrompido da vida de Euclides da Cunha, p. 182; ver também GALVÃO. O Império do Belo Monte.
} 
Vivendo quatrocentos anos no litoral vastíssimo, em que palejam reflexos da vida civilizada, tivemos de improviso, como herança inesperada, a República. Ascendemos, de chofre, arrebatados na caudal dos ideais modernos, deixando na penumbra secular em que jazem, no âmago do país, um terço da nossa gente. Iludidos por uma civilização de empréstimo; respingando, em faina cega de copistas, tudo o que de melhor existe nos códigos orgânicos de outras nações, tornamos, revolucionariamente, fugindo ao transigir mais ligeiro com as exigências da nossa própria nacionalidade, mais fundo o contraste entre o nosso modo de viver e o daqueles rudes patrícios mais estrangeiros nesta terra do que os imigrantes da Europa. Porque não no-los separa um mar, separam-no-los três séculos... (p. 138)

Ao estudar as culturas andinas, Henrique Urbano afirma ser a tradição filha dileta da modernidade, que, ao definir-se como única possibilidade de acesso ao conhecimento, a projetou na história como recalque de uma época em que reinava o Absoluto, com seus modelos míticos de conhecimento potencializados pelo terror das origens. Uma vez deixada à margem, a tradição seguiu seu próprio curso autônomo e se apresentou aos grupos espoliados como projeto político de reconstrução da sociedade, baseado na autoridade da memória sobre os fatos pretéritos e no resgate dos valores que haviam sido varridos para o lixo da história, bem como na negação da razão crítica. Como a modernidade teve sua expansão associada ao desenvolvimento da escrita e esta não conheceu os interiores das várias nações latino-americanas até bem entrado o século $\mathrm{XX},{ }^{27}$ a tradição tomou a si o trabalho de significar a vida que se desenrolava naquelas paragens, erigindo-se como alternativa social e política para os vastos grupos que ficaram à margem da modernização que se realizava no continente. Em outras palavras, o sertão não era um espaço virtualmente vazio, mas pleno de sentidos, que nascia de uma racionalidade fundada na tradição místico-religiosa.

As expedições sobre Canudos tornam o sertão um campo de batalha, em que se enfrentam duas estranhas ladainhas: de um lado o rugir dos canhões, e do outro, as vozes das rezas e dos cantos, expressões de duas formas de conhecimento, duas racionalidades de natureza oposta, que assumem indistintamente as formas do moderno e do arcaico. Para narrar o desigual embate entre "o legislador Comblain", com seu discurso "único, incisivo, supremo e moralizador - a bala" e as antigas táticas de luta dos sertanejos, que incluíam de paus a xingos e impropérios, Euclides invoca a imagem da luta entre a sucuri flexuosa contra o touro pujante:

Laçada a presa, distendia os anéis; permitia-lhe a exaustão do movimento livre e a fadiga da carreira solta; depois se constrangia repuxando-o, maneando-o nas roscas contráteis, para relaxá-las de novo, deixando-os mais uma vez se esgotar no escarvar, a marradas, o chão; e novamente o atrair, retrátil, arrastando-o... (p. 288)

Essa imagem, prevista no assalto dos jagunços sobre a tropa em Tabuleirinhos quando um "mamaluco possante", "um campeador terrível”, avançou sobre um dos canhões e "o abarcou nos braços musculosos, como se estrangulasse um monstro", imprecando em alta voz: "viram, canalhas, o que é ter coragem?!" - torna-se alegoria da apropriação que o bárbaro realiza sobre o civilizado, no coração do sertão. A imagem dessa apropriação

\footnotetext{
${ }^{27}$ Canclini, citando Renato Ortiz, oferece números do analfabetismo no Brasil no final do século XIX. CANCLINI. Culturas híbridas, p. 68.
} 
figura como índice da sedução que o moderno derrama a sua volta, mas também como expressão do desejo do arcaico de se apropriar, devorar o novo, o que provém de outro tempo, de outro mundo, incorporando-o a si mesmo como única possibilidade de permanência. É por este gesto que o arcaico acredita poder sobreviver no futuro, agarrado à pele do novo, como sugeria Benjamin, em seu Projeto das Arcadas, sustentando que as formas do novo traziam dentro de si as gastas formas do passado que vinha substituir. ${ }^{28}$

Outra imagem peculiar, desta vez a de um menino preso pelas forças do governo, sugere essa apropriação como resultante de uma divertida montagem, em que a opção entre o moderno ou o antigo se fazia como jogo, mediando entre a habilidade e a necessidade. Esse garoto, "menor de nove anos", estava no meio dos soldados respondendo a diversas perguntas sobre as tropas conselheiristas, quando vê uma Comblain no braço de um soldado e arrisca um comentário sobre a qualidade da arma. Chamando-a de Comblé, dizia que não prestava por não ter força e que em seu lugar, preferia a "manulixe, um clavinote de talento"; após manuseá-la, passaram-lhe uma Manlincher, a qual "desarticulou agilmente os fechos, como se fosse aquilo um brinco infantil predileto". Essas cenas, contrastadas com o caráter incompleto da modernidade que chegou tardia, suscitam a reflexão sobre a impropriedade de pensá-las como um epifenômeno isolado das circunstâncias históricas que as fizeram aparecer no sertão brasileiro. Ali, na "terra ignota", brotava um território livre, híbrido, quase um posto avançado da pós-modernidade que tardaria um século para entender a troca como um signo gozoso, libertário, da diferença entre culturas de diferentes status. Mas também deixava claro o aparecimento de um vácuo, um vazio temporal entre o desejo do moderno e sua consumação, já que a modernização, segundo afirma Willy Thayer, trata-se de um conjunto de práticas, "sem meta-relato de sentido e sem teoria sobre o solo, ou abismo, que sustenta", em direta oposição ao moderno, como um discurso transcendente de sentido ligado à emancipação do sujeito. Essa apropriação incompleta esterilizou o desejo de ser moderno na frustrada repetição paródica da modernidade européia e não criou as condições necessárias para que razão crítica pudesse refletir sobre suas próprias condições de possibilidade, em seu "foro interno". ${ }^{29}$

A imagem em que a sucuri e o touro, presos ao couro um do outro, executam seu trágico balé da morte, do qual resultarão mais de 15 mil mortos, resume a multiplicidade de gestos violentos que os colocaram em combate: o discurso científico da superioridade racial, como fruto do determinismo histórico que a civilização ocidental carrega em seu ventre, contra o obscurantismo místico que apregoa a comenda eterna aos guerreiros da fé, sedentos de sacrifícios humanos como prova de sua lealdade cega. Na verdade, dois princípios que brotam do mesmo escrutínio histórico em que a razão se ausentou, o que colocou patrícios em armas, uns contra os outros, e tornou Canudos um lugar vazio: "Era um parêntese; era um hiato; era um vácuo. Não existia. Transposto aquele cordão de serras, ninguém mais pecava." Ali a nação se dividia, como sentiam os soldados que chegavam:

\footnotetext{
${ }^{28}$ BUCK-MORSS. Dialética do olhar, p. 145-199.

${ }^{29}$ THAYER. A crise não moderna da universidade moderna, p. 139-143.
} 
Viam-se em terra estranha. Outros hábitos. Outros quadros. Outra gente. Outra língua mesmo, articulada em gíria original e pinturesca. Invadia-os o sentimento exato de seguirem para uma guerra externa. Sentiam-se fora do Brasil. A separação social completa dilatava a distância geográfica; criava a sensação nostálgica de longo afastamento da pátria.

$[\ldots]$

Convinha-se em que era terrivelmente paradoxal uma pátria que os filhos procuravam armados até os dentes, em som de guerra, despedaçando as suas entranhas a disparos de Krupps, desconhecendo-a de todo, nunca a tendo visto, surpreendidos ante a própria forma da terra árida, e revolta, e brutal, esvurmando espinheiros, tumultuando em pedregais, esboroando em montanhas derruídas, escanceladas em grotões, ondeando em tabuleiros secos, estirando-se em planuras nuas, de estepes...

O que ia fazer-se era o que haviam feito as tropas anteriores - uma invasão - em território estrangeiro. Tudo aquilo era uma ficção geográfica. (p. 348)

Eram brasileiros em armas contra brasileiros, desconhecidos uns dos outros, retalhando o discurso nacional que o livro de Euclides tentava suturar, a contrapelo dos acontecimentos, à margem das explicações. Eram exilados em cada lado da contenda: os sertanejos, "mais estrangeiros nesta terra do que os imigrantes da Europa", e os soldados, que "sentiam-se fora do Brasil", lutando não por uma nação, mas por uma "ficção geográfica" que brotava da narrativa euclidiana. Daí a referência que o narrador utiliza para falar do povoamento do país, passados cem anos de seu descobrimento, seja atualizado para o quadro final dos combates: "O Brasil era a terra do exílio". Naquela terra da diáspora, última fronteira em que as práticas e sua narrativa aparecem divorciadas, região onde soçobram as ruínas de uma nacionalidade construída com referências externas, uma nova cartografia parece desenhar-se com a irrupção de um protagonista até então pouco conhecido, o povo. Como elemento performativo que se produz na ambivalência do discurso nacional, ao reclamar sua existência conflitiva dentro de um tempo presente, contemporâneo, obstrui a prevalência do elemento pedagógico da nação, ao suspender sua remissão historicista a um passado comum. Como sugere Homi Bhabha, é este povo que introduz a "temporalidade do entre-lugar" como possibilidade aberta de redefinição das fronteiras internas da nação, elegendo a identificação cultural, e não a identidade, que é fruto da sedimentação histórica, como estratégia de auto-conhecimento e produção do próprio saber sobre si mesmo. ${ }^{30}$ Talvez isso possa explicar por que os procedimentos de matar e morrer no conflito sejam semelhantes, como a degola, por exemplo, ou as conversas animadas entre soldados e conselheiristas que ocorriam nos períodos de trégua, ou mesmo as vaias e impropérios que se lançavam mutuamente: eram todos tão parecidos, tão iguais, que a narrativa por vezes os descreve com os mesmos termos, suspendendo o tempo da beligerância, o tempo vazio e homogêneo do discurso nacional que precisava contê-los em campos opostos, como rivais destinados uns à vitória e outros à derrota.

Daí talvez também se possam entender as indecisões do narrador ao "escrever a nação", oscilando entre "a temporalidade continuísta, cumulativa, do pedagógico e a

\footnotetext{
${ }^{30}$ Esse povo, ou "multidão", termo deleuziano com que Juan Antonio Hernández ressalta seu caráter irredutível e inassimilável, está numa "relação de exterioridade e antagonismo com o Estado nacional", mas ao mesmo tempo se torna "parte de uma arqueologia do povo brasileiro", segundo este crítico. Ver HERNÁNDEZ. Los residuos salvajes: multitud y máquina de guerra en Los sertones de Euclides da Cunha.
} 
estratégia repetitiva, recorrente, do performativo." ${ }^{31}$ Nas margens do relato nacional que Euclides se esforça para consumar, aparece assim uma região de intensa troca de símbolos e mercadorias, como uma imensa feira pós-moderna onde os protagonistas negociam os símbolos de sua sobrevivência. Num desses intercâmbios, o sertão se transporta para dentro dos muros da cidade modernizada, o Rio de Janeiro, como marca indelével da existência de um espaço simbólico que ficou marcado na história nacional pela inconsciência da guerra.

\section{A VINGANÇA DO SERTÃO: A FAVELA NA CIDADE}

Sílvio Romero, no discurso de recepção a Euclides da Cunha na Academia Brasileira de Letras, após a saudação ao novo imortal, entra numa digressão sobre os problemas nacionais, concluindo com a necessidade premente do trabalho e da escolarização para o progresso do país: "trabalhemos, eduquemo-nos, reformemo-nos para viver..." Em seu discurso, o crítico faz referência ao intenso processo de urbanização pelo qual estaria passando o Rio de Janeiro, capital federal da República, contrastando-o com as demandas reais da modernização do país, quais sejam, acabar com o analfabetismo, a miséria, a falta de justiça, entre outras. Invocando um diálogo imaginário com um viajante estrangeiro, sustenta que o país se ilude com a civilização que acredita estar tomando contato, e conclui com tristeza:

Despediu-se e deixou-me triste. Tinha-se desmoronado, a meus olhos, todo o prestígio da Avenida à Beira-Mar, por onde eu já andava a ver desfilar o Brasil glorioso e próspero, dando leis ao mundo... E mais ainda essa fantástica raridade do Canal do Mangue, que devia ofuscar todas as Venezas existentes e por existir... ${ }^{32}$

Referia-se às mudanças que a Reforma Pereira Passos havia produzido na cidade, nos anos de 1902 a 1906, transformando radicalmente o espaço urbano carioca, que passou a expressar valores modernos e cosmopolitas em sua área central. Um dos resultados desta reforma, no entanto, foi a progressiva ocupação dos morros cariocas por famílias de migrantes que chegavam à capital naquele então. Muitos soldados que regressam de Canudos vão viver em terrenos nesses morros, que recebem como indenização de guerra, sendo que alguns deles traziam consigo mulheres que tomaram como despojo de guerra entre os sobreviventes do arraial de Antonio Conselheiro. ${ }^{33}$

Finalmente o sertão se vingava. A sua modernização, que se deu "através dos clarões das descargas", implicava um duplo apagamento: o primeiro era o seu próprio passado que precisava ser apagado e reescrito, o que efetivamente vai se completar na segunda metade dos anos 60, quando o Governo Militar inaugura o açude de Cocorobó, que cobriu a região onde Antonio Conselheiro plantou seu arraial, acabando com um triste passado de histórias de secas e sofrimento. Com outra mão, se apagavam os rastros dos que produziram o desastre, como uma mancha que enodoava a história nacional,

\footnotetext{
${ }^{31}$ BHABHA. O local da cultura, p. 198-238.

${ }^{32}$ ROMERO. Discurso pronunciado aos 18 de dezembro de 1906, por ocasião da recepção do Dr. Euclides da Cunha na Academia Brasileira de Letras, p. 158.

${ }^{33}$ Ver semelhante raciocínio em GARRAMUÑO. Pueblo sin estado.
} 
quando a partir dos anos trinta Os sertões são retomados como a epopéia fundacional da nação e o papel do Exército no episódio foi sendo revisto. Mas, por outro lado, a marca mais visível dessa empresa modernizadora implicará no traslado do nome de um dos morros que circundava Canudos, o morro da Favela, para a cidade do Rio de Janeiro, levado pelos combatentes cariocas, que responderá, num futuro que é o atual hoje, pelo lugar símbolo da barbárie urbana contemporânea. O trágico desfecho do conflito trazia consigo uma desconhecida premonição profética que dizia que "a correria do sertão entrava arrebatadamente pela civilização adentro.” Dessa maneira, a sucuri flexuosa morria atada ao touro pujante, o sertão se estendia pelas avenidas da cidade, o arcaico florescia viçoso, remoçado, no desenho da novíssima urbanidade que embalava a capital da República. Na resposta do menino ao ser perguntado se havia atirado com as armas que lhes mostravam, a travessia, enfim, se completava: “- E por que não? Pois se havia tribuzana velha!... Havera de levar pancada, como boi acuado, e ficar quarando à toa, quando a cabrada fechava o samba desautorizando as praças?!” (p. 354) A favela, reduto do samba, expressão da música nacional, brotara de um passado distante e sangrento, esquecido nas páginas dos livros, mas rememorado diariamente nas páginas folclóricas e policiais do Rio de Janeiro.

\section{(4)}

\section{RESUMEN}

Este ensayo reflexiona sobre el episodio de la travesía del Cambaio, de la novela Os sertóes (1902) de Euclides da Cunha. Plantea la construcción del espacio del conflicto desde el supuesto de que la fundación de la nación latinoamericana, aquí tomada como una hipérbole de la nación brasileña, incorporó principios de corte excluyente que dividieron al país en zonas de atraso y de progreso, lo que resultó en una rara profecía que vino a cumplirse cien años después.

\section{P A L A B R A S - CLA VE}

Sertón. Nación. Canudos.

\section{REFERÊNCIAS}

ANDRADE, Ana Luiza. Nordeste desertificado e docilizado: a economia dos sertões, uma paisagem entre palavra e imagem. Outra travessia, Revista de Literatura, Ilha de Santa Catarina, dossiê "da Cunha Euclides de cunhas", n. 2, p. 23-37, 1. sem. 2004.

BHABHA, Homi K. O local da cultura. Belo Horizonte: Editora UFMG, 1998.

BUCK-MORSS, Susan. Dialética do olhar: Walter Benjamin e o Projeto das Passagens. Belo Horizonte: Editora UFMG, 2002.

CALVINO, Italo. O cavaleiro inexistente. São Paulo: Companhia das Letras, 1993.

CANCLINI, Néstor García. Culturas híbridas: estratégias para entrar e sair da modernidade. 2. ed. São Paulo: Edusp, 1998.

CORNEJO POLAR, Antonio. O condor voa: literatura e cultura latino-americanas. Trad. Ilka Valle de Carvalho. Belo Horizonte: Editora UFMG, 2000. 
CUNHA, Euclides da. Os sertões. 34. ed. Rio de Janeiro: Francisco Alves, 1989.

GALVÃO, Walnice Nogueira. O Império do Belo Monte: vida e morte de Canudos. São Paulo: Fundação Perseu Abramo, 2002.

GALVÃO, Walnice Nogueira; GALOTTI, Oswaldo. Correspondência de Euclides da Cunha. São Paulo: Edusp, 1997.

GARRAMUÑO, Florencia. Pueblo sin estado: Los sertones y el imaginario moderno. Outra travessia, Revista de Literatura, Ilha de Santa Catarina, dossiê "da Cunha Euclides de cunhas”, n. 2, p. 39-51, 1. sem. 2004.

HAUSSER, Christian K. A Guerra de Canudos na memória nacional: os manuais de história. In: ALMEIDA, Ângela Mendes de; ZILLY, Berthold; LIMA, E. N. (Org.). De sertões, desertos e espaços incivilizados. Rio de Janeiro: MAUAD; Faperj, 2001. p. 157-172.

HERNÁNDEZ, Juan Antonio. Los residuos salvajes: multitud y máquina de guerra en Los sertones de Euclides da Cunha. Revista Iberoamericana, Pittsburgh, v. LXX, n. 207, p. 443-453, abr.-jun. 2004.

LAGES, Suzana Kampff. Entremeio: a melancolia em Walter Benjamin - traços. In: . Walter Benjamin: tradução e melancolia. São Paulo: Edusp, 2002. p. 99-159.

NASCIMENTO, José Leonardo do; FACIOLI, Valentim (Org.). Juízos críticos: Os sertões e os olhares de sua época. São Paulo: Nankin Editorial; Editora Unesp, 2003.

NIETSZCHE, Friedrich. Sobre verdade e mentira no sentido extramoral. In: Nietszche. São Paulo: Nova Cultural, 2005. p. 51-60. (Coleção Os pensadores)

RENAN, Ernest. ¿Qué es una nación? In: BRAVO, Álvaro Fernandéz (Comp.). La invención de la nación. Buenos Aires: Manantial, 2000. p. 53-66.

ROMERO, Sílvio. Discurso pronunciado aos 18 de dezembro de 1906, por ocasião da recepção do Dr. Euclides da Cunha na Academia Brasileira de Letras. In: NASCIMENTO, José Leonardo do; FACIOLI, Valentim (Org.). Juízos críticos: Os sertões e os olhares de sua época. São Paulo: Nankin Editorial; Editora Unesp, 2003. p.123-158.

SALLES, Maria Inês P. C. Cicatrizes submersas d'Os sertões: Descartes Gadelha e Euclides da Cunha em correspondência. Fortaleza: Cone Sul, 1999.

URBANO, Henrique. La tradición andina o el recuerdo del futuro. In: - (Org.)

Tradición y modernidad en los Andes. Cusco: Centro de Estudios Regionales Bartolomé de las Casas, 1997. p. VII-L.

THAYER, Willy. A crise não moderna da universidade moderna. Belo Horizonte: Editora UFMG, 2002.

VENTURA, Roberto. Retrato interrompido da vida de Euclides da Cunha. São Paulo: Companhia das Letras, 2003.

ZILLY, Berthold. A barbárie: antítese ou elemento da civilização? Do Facundo de Sarmiento a Os sertões de Euclides da Cunha. In: ALMEIDA, Ângela Mendes de; ZILLY, Berthold; LIMA, E. N. (Org.). De sertões, desertos e espaços incivilizados. Rio de Janeiro: MAUAD; Faperj, 2001. p. 271-301. 